\title{
The lleuque forests of South Central Chile: a phytosociological study and syntaxonomical classification within South American temperate forests
}

\author{
Javier Amigo (*), Manuel A. Rodríguez-Guitián (**) \& Carlos Ramírez (***)
}

\begin{abstract}
Amigo, J., Rodríguez-Guitián, M.A. \& Ramírez, C. The lleuque forests of South Central Chile: a phytosociological study and syntaxonomical classification within South American temperate forests. Lazaroa 31: 85-98 (2010).

This paper is a phytosociological study of a forest community dominated by the lleuque (the Araucanian name for the podocarpaceae Prumnopitys andina). This is a mixed forest community with gymnosperm and broad-leaved trees growing in a temperate sub-Mediterranean climate, with a somewhat continental character within the very oceanic territory of Chile. The paper describes the new Nothofago obliquae-Prumnopitydetum andinae association, mostly located between the BíoBío and La Araucanía regions (parallels $36^{\circ}$ to $40^{\circ}$ south). We deal with the bioclimatic characteristics of the community, its biogeographical restrictions and its continuing presence in special topographical sites. The paper not only analyzes the floristic composition of the community in order to ascribe it syntaxonomically to the Wintero-Nothofagetea class, but also considers a number of floristic arrangements which support a reinterpretation of some syntaxa which are phytosociologically ranked as orders or classes.
\end{abstract}

Key words: Prumnopitys andina, endangered flora, continental forests, temperate forests, Wintero-Nothofagetea, Nothofagetea pumilionis-antarcticae.

Resumen: Amigo, J., Rodríguez-Guitián, M.A. \& Ramírez, C. Los bosques de lleuque del Centro-Sur de Chile: estudio fitosociológico y posición sintaxonómica dentro de los bosques templados de Sudamérica. Lazaroa 31: 85-98 (2010).

Se presenta el estudio fitosociológico de una comunidad de bosque presidida por el lleuque (nombre de origen araucano de la podocarpácea Prumnopitys andina). Se define como un bosque mixto con mezcla de gimnospermas y planifolios, de tipo templado sub-Mediterráneo y con cierto matiz de continentalidad dentro de un territorio tan oceánico como Chile. Se describe una nueva asociación denominada Nothofago obliquae-Prumnopitydetum andinae con una distribución principal entre las regiones del Bío-Bío y la Araucanía (paralelos $36^{\circ}$ a $40^{\circ}$ Sur); se comentan las características bioclimáticas, sus limitaciones biogeográficas y su persistencia en posiciones topográficas peculiares. Además de analizar su composición florística para su encuadre sintaxonómico dentro de la clase Wintero-Nothofagetea se realizan consideraciones sobre algunos colectivos florísticos que apoyan reinterpretaciones de algunos sintaxones del rango de orden o de clase fitosociológica.

Palabras clave: Prumnopitys andina, flora amenazada, bosques continentales, bosques templados, Wintero-Nothofagetea, Nothofagetea pumilionis-antarcticae.

\section{INTRODUCTION}

The lleuque [Prumnopitys andina (Poepp. ex Endl.) de Laub] is a gymnosperm, a practically en- demic plant of Chile, which occurs in some temperate forests located on a strip of land extending approximately from parallel $35^{\circ} 50^{\prime}$ to $40^{\circ} 30^{\prime}$ south (CONAF 1998). It grows mostly in the lower va-

* Laboratorio de Botánica, Facultad de Farmacia, Universidad de Santiago de Compostela. E-15782 Santiago de Compostela (Galicia, España).E-mail: javier.amigo.vazquez@usc.es

** Departamento de Producción Vexetal. Escola Politécnica Superior de Lugo. Universidad de Santiago de Compostela. 27002-Lugo

*** Instituto de Botánica, Universidad Austral de Chile. Casilla 567, Valdivia (Chile). 
lleys of the Andean Cordillera and, to a much lesser extent, in rain shadow sites of some areas of the Cordillera de la Costa (Nahuel Buta and Cordillera Pelada), under extremely difficult conditions for its survival (Figure 1). In a comprehensive assessment following UICN criteria (HECHENLEITNER \& al., 2005), the lleuque populations have recently been ranked as vulnerable, VU (B2ab).

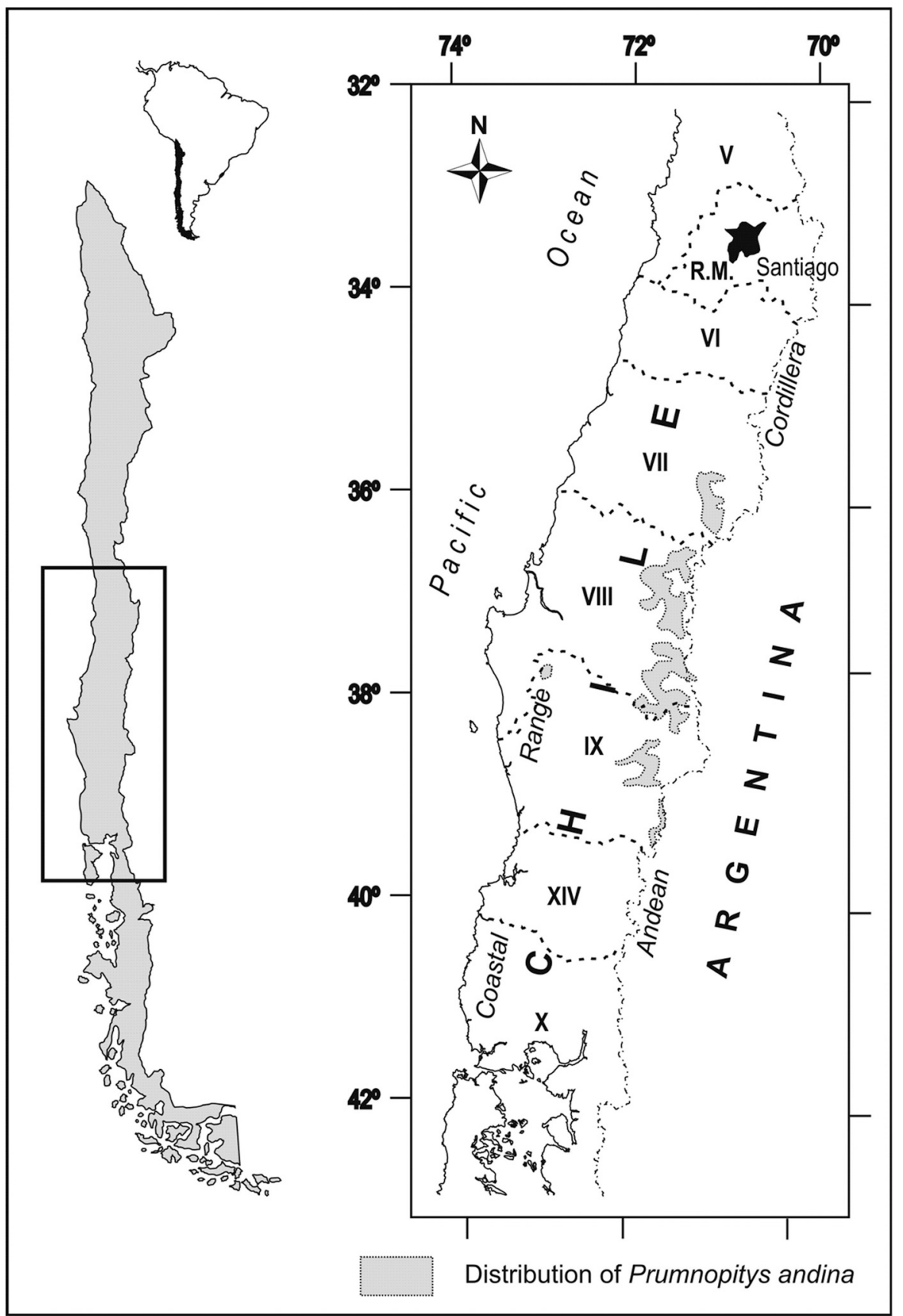

Figure 1.- Location of natural populations of Prumnopitys andina in Chilean territory. Based on CONAF (1998), HECHENLEITNER \& al. (2005) and on our own data. 
Prumnopitys andina, the most suitable name for this plant species belonging to the Podocarpaceae family, should prevail over Podocarpus andina or Prumnopitys spicata (see MiLL \& QuinN 2001). General works, such as those by DonOSO (1983), RoDRíGUEZ \& al. (1983), RoDRÍGUEZ (1988) or RODRíGUEZ \& QUEZADA (1995), have already sufficiently described this Chilean (and only in very specific places) Argentinian tree (Zuloaga \& Morrone 1996) with regards its botanical and morphological characteristics (leaves, flowers, etc.). However, these descriptive approaches deal very little with the tree's sociological behaviour or companion species (apart from some brief comments on its ecological requirements). As a result of the ecological preferences of the tree, it seldom gives rise to extensive formations, a fact which has made the tree appear to be of minor importance not only for descriptive works dealing with Chilean vegetation (GAJARDO, 1994), but also for works to classify it for forestry purposes (DoNOSO, 1981).

Recent studies confirmed by experts such as HeCHENLEITNER \& al., (2005) suggest that the lleuque is geographically an extremely restricted coniferous tree, after only the pehuén (Araucaria araucana) and the alerce (Fitzroya cupressoides), the most restricted of all. Consequently, we must dismiss prior interpretations which allegedly recorded its occurrence as far as parallel $45^{\circ}$ south (WolTZ, 1985) as incorrect and obviously based on confusion with another species endemic to Chile: Podocarpus nubigena. Whereas alerce and pehuén are large-sized, coniferous tree species (adult individuals can grow up to 30 metres or more) capable of dominating forest masses over their angiosperm companions, the lleuque barely reaches $20 \mathrm{~m}$ at the most, and usually only reaches $12-16 \mathrm{~m}$ in height. The lleuque is therefore forced to co-exist in its distribution area with other potentially taller tree species such as the roble (Nothofagus obliqua), the coihue (Nothofagus dombeyi) and even the ciprés de la cordillera (Austrocedrus chilensis).

More than two decades ago, one of the authors proposed an association characterized by the lleuque. In a phytosociological synthesis, RAMírEz \& FIGUEROA (1985) suggested the association named
Prumnopito-Nothofagetum obliquae nomen nudum, which was basically characterized by the occurrence of Chilean oaks associated with these coniferous trees. Since there were no supportive relevés at the time, the proposed association was invalid according to the requirements of the Code of Phytosociological Nomenclature (WEBER \& al., 2000) and remained as a nomen nudum. The name was hardly ever used again in any descriptive botanical work. The only exception was a compilation by LuEBerT \& PLISCOFF (2006), who mentioned it as one of the zonal communities which could be found in the territorial area of their unit 54: "Temperate, caducifolious Nothofagus obliqua and Laurelia sempervirens forest".

Aware of the content vacuum around the nomen nudum status, we took up the topic again and carried out a number of relevés in order to properly define the floristic composition, map the chorological distribution and determine the bioclimatic preferences, dynamic aspects and possible exploitation of these wood formations where lleuque occurs. Our records suggest that all these characteristics indicate a genuine phytosociological association.

\section{METHODOLOGY}

We explored the areas of Chile where the occurrence of lleuque had been massively recorded. For this purpose we visited different areas of the valleys at the foot of the Andean Cordillera throughout the regions of Bío-Bío and La Araucanía (VIII ${ }^{\text {th }}$ and IX $^{\text {th }}$ regions, respectively, in the Chilean administrative arrangement; see Figure 1). Our aim was to sample plant formations with a considerable presence of lleuque trees, with a more or less natural appearance and a homogeneous wood mass, dismissing any man-induced discontinuities. In these sites we made relevés using the phytosociological method of BRAUNBlANQUet (1979), later updated by GéHU \& RIVAS-MARTíNEZ (1981).

To determine the species growing in each sampling area we followed the nomenclature suggested by Marticorena \& QueZada (1985) and MARTICORENA \& RodRíguEZ (1995, 2001, 2003 
and 2005). For syntaxonomical purposes, we complied with the directives of the $3^{\text {rd }}$ edition of the Code of Phytosociological Nomenclature (WEBER \& al., 2000).

\section{RESULTS}

The lleuque populations in the Cordillera de la Costa are so small and their natural environment has been so dramatically altered by Pinus reforestation that we will omit the forest relevés including this species in this area of Chile. In the distribution area, in the foothills of the Andean Cordillera, there are occasional forest patches dominated by lleuque trees (and variably shared with broad-leaved species, mostly belonging to the Nothofagus genus). As we will discuss later, Prumnopitys andina tends to grow on the lower levels of the mountain slopes, that is, where it can most easily form extensive populations on considerably large sites. However, in the pre-Cordilleran valleys where the community has its optimum, natural environments have also been dramatically altered by the native mapuche population. For this reason, although scattered mature trees and sometimes even tree copses are frequently found, the understorey has often been reduced to a minimal expression by cattle-farming (goats, cows and horses) activities. Examples are abundant in all the river valleys with headwaters in the Andean pre-Cordillera. We have found lleuque copses, for instance, in the valleys of the rivers Nuble, Queuco, Bío-Bío and Toltén.

In spite of all this, we were also able to sample some sufficiently natural formations in which, as they were in topographical locations which were fairly inaccessible to cattle, human action seems to have had little or no impact on the configuration of the forest. Table 1, with a total of 14 relevés, comprises all these samples supporting our proposal for the new association Nothofago obliquae-Prumnopitydetum andinae Amigo, Rodríguez-Guitián \& Ramírez ass. nova hoc loco (holotypus rel. 7, Table 1).

The new community shows not only the constant affinity of lleuque for roble (Nothofagus obliqua) but also the ability of lleuque to join up with other trees having rather opposite ecological preferences. An example is coihue (Nothofagus dombeyi), with which it forms more shady arrangements as a result of their shared evergreen character. It also joins up with the ciprés de la cordillera (Austrocedrus chilensis), a more heliophilous and to a certain extent xerophilous species. This last matching reveals a somewhat sub-Mediterranean influence in the formations shared by these coniferous trees.

\section{DISCUSSION}

\section{ABOUT THE HABITAT}

We think that it is correct to say that Prumnopitys andina grows "mostly at the bottom of valleys near large rivers" (HECHENLEITNER \& al., 2005). However, the forest patches in which this coniferous tree may become dominant show an edaphotopographical peculiarity: they tend to be located on colluvial deposits of large rocky blocks, often at the foot of cliffs or steep slopes (Figure 2), in an ecological environment which resembles the European forests belonging to the Tilio-Acerion Klika 1955 (ELLENBERG, 1988) alliance. The lleuque's ability to germinate and develop on deep, very stony soils has probably provided it with efficient survival options to defend itself against the human colonization of the valley floors and the usual activities that ensue: land deforestation, farming and cattle-raising and human settlement. It is well known that in sites which have been partly deforested for cattle-farming activities but where adult lleuque trees have been maintained, these trees no longer regenerate because pigs and goats eat their fleshy seeds (HECHENLEITNER \& al., op. cit., Figure 3).

\section{ABOUT THE CHOROLOGICAL AND BIOCLIMATIC DIAGNOSIS}

The new association suggested is endemic to the temperate territory, which is more or less coincidental with the Subantarctic Province in the biogeographical arrangement by CABRERA \& 



Figure 2.- Preferential topographical locations of the Nothofago obliquae-Prumnopitydetum andinae forests under study.

WiLLINK (1973), or the Valdivian-Magallanic Region, according to the chorological scheme suggested by Rivas-Martínez (see in CosTA, 2004). In default of other more detailed biogeographical sectorization models, in the mapping suggested by LUEBERT \& PlisCOFF (2006) this association would be part of the "Caducifolious forest" plant formation and of the vegetation belt called "Caducifolious temperate Nothofagus obliqua and Laurelia sempervirens forest" (hereafter "forest no. 54 roble-laurel").

The bioclimatic indexes of sites not only on the mountain peaks but also on the foothills of the Cordillera cannot be accurately calculated as there are no suitable weather stations in the Andean areas of Chile. Nevertheless, the records measured at the nearby Lonquimay weather station (Amigo \& al., 2007a), at an altitude of 900 $\mathrm{m}, 38^{\circ} 26^{\prime}$ south and $71^{\circ} 15^{\prime}$ west, can be taken as approximate values. According to the scheme suggested by Rivas-MARTínEZ (1993, 2007, On-
Line), these bioclimatic records clearly belong to the upper supratemperate $(\mathrm{Tp}=1005)$ and upper hyperhumid $(\mathrm{Io}=19.1)$ ranges. Taking into account these records and the sampled altitudinal range (630-925 m), the geographical areas colonized by the Nothofago obliquae-Prumnopitydetum andinae association show a bioclimatic profile which corresponds to a supratemperate thermotype. Consequently, we categorically reject the subordination of the name "PrumnopytoNothofagetum obliquae" with its vegetation belt "forest no. 54 roble-laurel" suggested by LUEBERT \& PLISCOFF (op.cit.), since these authors ascribe fluctuation ranges of Itc $=223-273$ and Tp $=1238-1440$ to that belt. These values clearly correspond to a bioclimatically mesotemperate belt.

The clearest bioclimatic peculiarity associated with the distribution of lleuque forests is a certain degree of continentality. Most of the territories where they occur (we exclude here the vestigial sites of the Cordillera de la Costa) are clearly se- 
Table 1

Nothofago obliquae-Prumnopitydetum andinae ass. nova

(Austrocedro-Nothofagion dombeyi, Berberido trigonae-Nothofagetalia dombeyi, Wintero-Nothofagetea)

\begin{tabular}{|c|c|c|c|c|c|c|c|c|c|c|c|c|c|c|}
\hline $\begin{array}{l}\text { Altitude } \\
\text { (m a.s.1.) }\end{array}$ & 630 & 735 & 800 & 925 & 725 & 800 & 800 & 865 & 760 & 750 & 830 & 730 & 860 & 750 \\
\hline Slope $\left(^{\circ}\right)$ & 16 & 30 & 35 & 10 & 34 & 40 & 40 & 35 & 15 & 10 & 30 & 26 & 5 & 32 \\
\hline Aspect & SE & $\mathrm{NE}$ & WSW & NNE & $\mathrm{NE}$ & $\mathrm{NE}$ & SSW & NNE & $\mathrm{NE}$ & SSE & W & NNW & SW & ESE \\
\hline Cover $(\%)$ & 100 & 100 & 90 & 95 & 100 & 95 & 90 & 90 & 90 & 100 & 95 & 95 & 80 & 70 \\
\hline Vegetation hight (m) & 18 & $12-14$ & $12-22$ & $20-28$ & $16-18$ & $15-26$ & $615-20$ & $15-17$ & $12-15$ & $12-14$ & $14-20$ & $15-20$ & $10-18$ & $8-13$ \\
\hline Plot area $\left(\mathrm{m}^{2}\right)$ & 200 & 200 & 500 & 500 & 300 & 300 & 250 & 250 & 120 & 200 & 400 & 300 & 100 & 100 \\
\hline $\mathrm{N}^{\mathrm{o}}$ of species & 32 & 26 & 22 & 23 & 23 & 28 & 30 & 25 & 25 & 24 & 25 & 15 & 18 & 21 \\
\hline N. & 1 & 2 & 3 & 4 & 5 & 6 & 7 & 8 & 9 & 10 & 11 & 12 & 13 & 14 \\
\hline
\end{tabular}

Dominant trees

$\begin{array}{llllllllllllllllll}\text { Prumnopitys andina } & 5 & 4 & 4 & 4 & 5 & 5 & 5 & 5 & 5 & 3 & 5 & 4 & 3 & + & 14\end{array}$

Nothofagus obliqua

Austrocedrus chilensis

Nothofagus dombeyi



Characteristics of association and upper units

Chusquea culeou

Osmorhiza chilensis

Blechnum hastatum

Alstroemeria aurea

Lomatia hirsuta

Myoschilos oblonga

Maytenus chubutensis

Polystichum plicatum

Relchela panicoides

Viola maculata

Calceolaria filicaulis

Mutisia decurrens

Schinus patagonicus

Lomatia dentata

Vicia nigricans

Lathyrus subandinus

Sanicula crassicaulis

Pseudopanax laetevirens

Adenocaulon chilense

Bowlesia tropaeolifolia

Cystopteris fragilis

Trisetum caudulatum

Carex patagonica

Aristotelienea species

Relbunium hypocarpium

Azara microphylla

Aristotelia chilensis

Ribes gr. valdivianum

Berberis darwini

Rosa rubiginosa

Berberis microphylla

Boquila trifoliolata

Myrceugenia nanophylla

Azara integrifolia

Fuchsia magellanica

Companion species 


\begin{tabular}{|c|c|c|c|c|c|c|c|c|c|c|c|c|c|c|c|}
\hline N. & 1 & 2 & 3 & 4 & 5 & 6 & 7 & 8 & 9 & 10 & 11 & 12 & 13 & 14 & \\
\hline Adiantum chilense & $\cdot$ & 1 & $\cdot$ & . & + & + & . & . & + & $\cdot$ & . & + & . & $\cdot$ & 5 \\
\hline Dactylis glomerata & 1 & 1 & $\cdot$ & $\cdot$ & 1 & + & $\cdot$ & $\cdot$ & 1 & $\cdot$ & . & $\cdot$ & . & $\cdot$ & 5 \\
\hline Acaena ovalifolia & + & 1 & $\cdot$ & $\cdot$ & $\cdot$ & $\cdot$ & $\cdot$ & $\cdot$ & + & $\cdot$ & $\mathrm{r}$ & $\cdot$ & $\cdot$ & $\cdot$ & 4 \\
\hline Prunella vulgaris & + & + & $\cdot$ & $\cdot$ & + & + & . & $\cdot$ & $\cdot$ & $\cdot$ & $\cdot$ & $\cdot$ & $\cdot$ & $\cdot$ & 4 \\
\hline Solanum cyrtopodium & + & + & $\cdot$ & $\cdot$ & $\cdot$ & + & $\cdot$ & $\cdot$ & $\cdot$ & $\cdot$ & $\cdot$ & $\cdot$ & $\cdot$ & $\cdot$ & 3 \\
\hline Carex aphylla & $\cdot$ & $\cdot$ & $\cdot$ & + & $\cdot$ & $\cdot$ & $\cdot$ & $\cdot$ & $\cdot$ & $\cdot$ & $\cdot$ & + & . & 1 & 3 \\
\hline Leucheria caerulescens & $\cdot$ & $\cdot$ & + & $\cdot$ & $\cdot$ & $\cdot$ & 1 & $\cdot$ & $\cdot$ & $\cdot$ & $\cdot$ & $\cdot$ & . & 1 & 3 \\
\hline Valeriana cf. valdiviana & $\cdot$ & $\cdot$ & $\cdot$ & $\cdot$ & 1 & $\cdot$ & + & $\cdot$ & 1 & $\cdot$ & $\cdot$ & $\cdot$ & . & $\cdot$ & 3 \\
\hline Gaultheria phyllireifolia & + & $\cdot$ & $\cdot$ & $\cdot$ & $\cdot$ & $\cdot$ & $\mathrm{r}$ & $\cdot$ & + & $\cdot$ & $\cdot$ & $\cdot$ & $\cdot$ & $\cdot$ & 3 \\
\hline Lapsana communis & $\cdot$ & + & $\cdot$ & $\cdot$ & + & $\cdot$ & $\cdot$ & $\cdot$ & 1 & $\cdot$ & $\cdot$ & $\cdot$ & . & $\cdot$ & 3 \\
\hline Adiantum scabrum & $\cdot$ & $\cdot$ & $\cdot$ & $\cdot$ & $\cdot$ & $\cdot$ & . & $\cdot$ & $\cdot$ & $\cdot$ & . & + & · & 1 & 2 \\
\hline Gavilea sp. & $\cdot$ & $\cdot$ & $\cdot$ & $\cdot$ & $\cdot$ & + & $\cdot$ & $\cdot$ & $\cdot$ & 1 & $\cdot$ & $\cdot$ & $\cdot$ & $\cdot$ & 2 \\
\hline Dioscorea sp. & 1 & $\mathrm{r}$ & $\cdot$ & $\cdot$ & $\cdot$ & $\cdot$ & . & $\cdot$ & $\cdot$ & $\cdot$ & . & $\cdot$ & . & $\cdot$ & 2 \\
\hline Asplenium dareoides & + & $\cdot$ & $\cdot$ & $\cdot$ & + & $\cdot$ & $\cdot$ & $\cdot$ & $\cdot$ & $\cdot$ & $\cdot$ & $\cdot$ & $\cdot$ & $\cdot$ & 2 \\
\hline Agrostis leptotricha & $\cdot$ & $\cdot$ & + & $\cdot$ & $\cdot$ & $\cdot$ & $\cdot$ & $\cdot$ & $\cdot$ & $\cdot$ & . & $\cdot$ & $\cdot$ & 1 & 2 \\
\hline Nasella chilensis & . & . & $\cdot$ & . & . & $\cdot$ & . & . & $\cdot$ & $\cdot$ & . & 1 & + & $\cdot$ & 2 \\
\hline Acaena argentea & $\cdot$ & $\cdot$ & $\cdot$ & $\cdot$ & . & + & $\cdot$ & $\cdot$ & $\cdot$ & $\cdot$ & . & $\cdot$ & + & $\cdot$ & 2 \\
\hline Cynanchum pachyphyllum & . & . & $\cdot$ & . & . & $\cdot$ & . & . & + & 1 & . & . & $\cdot$ & $\cdot$ & 2 \\
\hline Equisetum bogotense & $\cdot$ & 1 & $\cdot$ & $\cdot$ & . & $\cdot$ & $\cdot$ & + & $\cdot$ & $\cdot$ & . & $\cdot$ & · & $\cdot$ & 2 \\
\hline
\end{tabular}

Other species: Characteristics species Azara lanceolata r, Blechnum mochaenum, Blechnum penna-marina and Rhaphithamnus spinosus +, Luma apiculata 1 in 1; Elymus andinus + in 4; Anemone multifida + in 8; Embothrium coccineum 1 in 9; Berberis rotundifolia $\mathrm{r}$ in 11; Gevuina avellana $\mathrm{r}$, Aextoxicon punctatum + , Drimys winteri and Muehlenbeckia hastulata 1, Laurelia sempervirens and Podocarpus saligna 2, Hydrangea serratifolia 3 in 13; Diostea juncea + in 14. Companion species: Polypodium feuillei + in 5; Loasa sp. r, Geranium robertianum and hemicryptophyte unknown + in 6; Asteracea sp. and Stellaria sp. + in 7; Holcus lanatus and Hypericum perforatum + , Lactuca serriola 1 in 8; Festuca scabriuscula + , Lotus uliginosus 1 in 9; Pernettya myrtilloides and Poacea sp. ,+ Rumohra adiantiformis 1 in 10; Poa gr. trivialis + in 11; Cirsium arvense, Solanum gr. gayanum and Tristerix tetrandrus + in 13; Baccharis concava, Cheilanthes glauca, Chusquea cumingii, Oxalis araucana and Satureja gilliesi +, Sophora macrocarpa 1, Gochnatia foliolosa and Quillaja saponaria 2 in 14.

Localities (author's code for relevés is included): 1,2, 5, 9 and 10: La Araucanía, Cautín, from Cahuilelfún towards Curarrehue, $39^{\circ} 15^{\prime}-71^{\circ} 26^{\prime}(070124 / 1)$; from Reigolil towards Curarrehue, 39 $11^{\prime}-71^{\circ} 27^{\prime}(070123 / 4)$; $39^{\circ} 12^{\prime}-71^{\circ} 27^{\prime}$ (070123/5); from Reigolil towards Curarrehue, 39¹1'-71²7' (090122/3); Conguillío National Park, Southwards exit to Melipeuco, 3845'-71³7' (070119/2); 3, 4, 6-8 and 11: La Araucanía, Malleco, Bio-Bio river valley, Casas de Lolco, 38 $08^{\prime}-71^{\circ} 24^{\prime}$ (090120/3); from Troyo Northwards, 38 $10^{\prime}-71^{\circ} 18^{\prime}$ (090120/2); between Contraco and Lolco, 38 $08^{\prime}-71^{\circ} 20^{\prime}$ (070118/5); Bio-Bio river valley, from Troyo Northwards, $38^{\circ} 11^{\prime}-71^{\circ} 18^{\prime}(070118 / 3)$, holotypus ass. Bio-Bio river valley, from Lonquimay towards Troyo, 38¹9'-71¹9' (090119/1); Nalcas National Reserve, from Casas de Lolco towards Lonquimay. 38¹1'-71²26' (090120/4); 12: Bío-Bío, Bío-Bío: river Queuco valley upwards, close to Comuna Cauñico, $37^{\circ} 43^{\prime}-71^{\circ} 23^{\prime}$ (070117/1); 13 and 14: Bío-Bío, Nuble: entrance to Nuble National Reserve, $36^{\circ} 58^{\prime}-71^{\circ} 30^{\prime}(080119 / 1)$; Nuble valley upwards, a little downwards from Los Sauces, 36 $40^{\circ}-$ $71^{\circ} 16^{\prime}(070115 / 2)$.

mihyperoceanic, sometimes even euoceanic. At the Lonquimay weather station, the Ic $=14.0$, that is, the threshold value between semihyperoceanic and euoceanic conditions. All these temperate territories are also bioclimatically characterized by their sub-Mediterranean character, that is, they undergo a certain degree of water deficit in summer time. Although there are no accurate weather records available, the distribution of Prumnopitys andina tends clearly to coincide with the non-co- astal area described by Luebert \& PliscofF (op.cit.: 66, Figure 14) as having a temperate subMediterranean bioclimate.

\section{ABOUT THE FLORISTIC COMPOSITION}

Although the analysis shown in Table 1 reveals some variability, the community as a whole presents a constant occurrence of nemoral species. In other words, the community is able to 


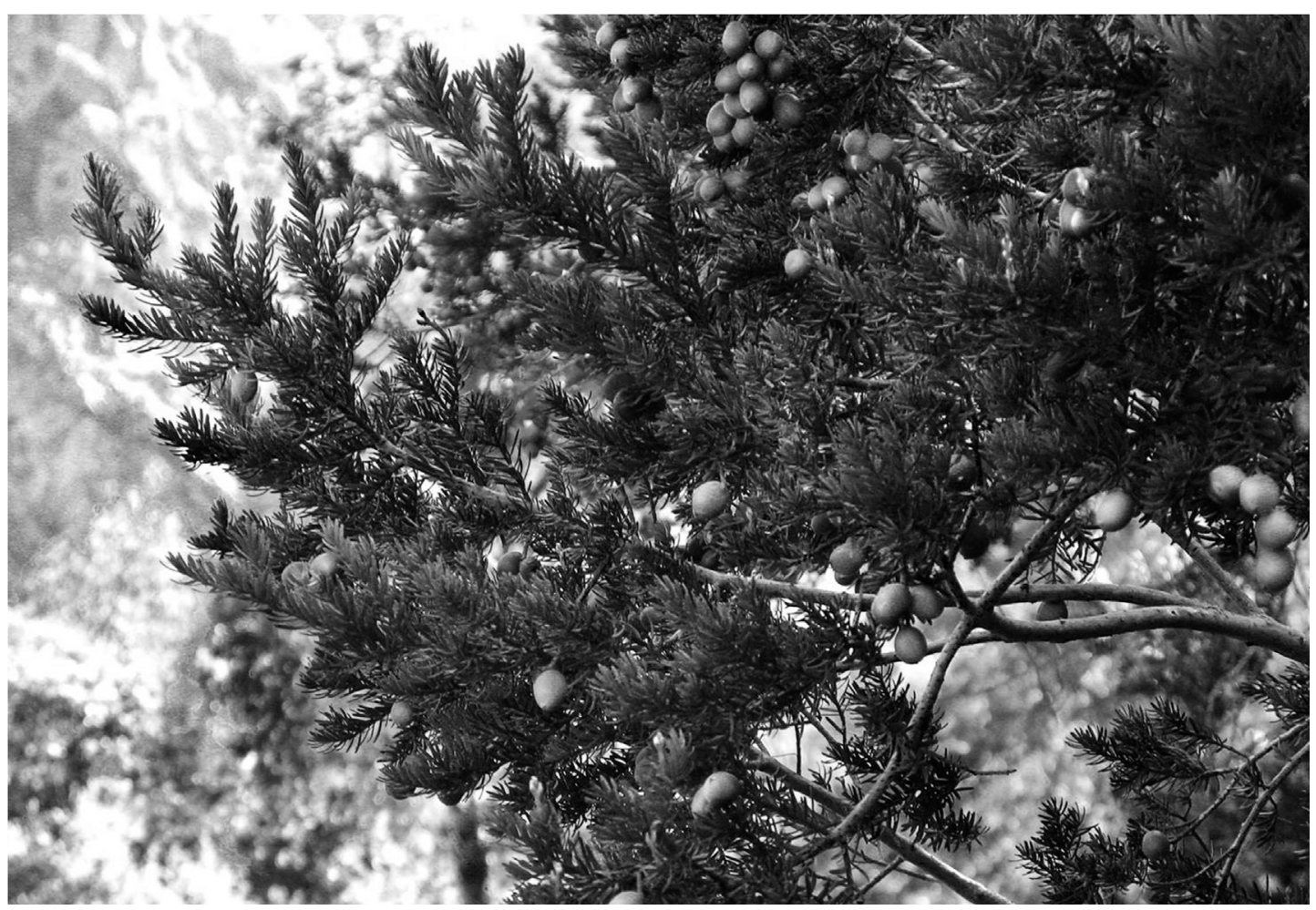

Figure 3.- Detail of seminiferous branches of Prumnopytis andina.

maintain an acceptable forest structure which becomes less defined as the sub-Mediterranean conditions become more apparent, and the copse physiognomy changes due to the progressively dominant presence of Austrocedrus chilensis. The combination of a coniferous tree, with a higher cover rate, and a deciduous species, such as Nothofagus obliqua, gives rise to a myriad of understorey microhabitats with extraordinarily changing light conditions (Figure 4) and very different contributions of dead leaves. The phenomenon is particularly prominent because it also frequently takes place on very irregular microtopographical terrains with abundant large rocky outcrops. These microhabitats induce the occurrence of species belonging to the whole range of biotypes peculiar to a temperate forest. Included in this last group, the scrub species which present their optimum in the wood mantles of temperate forests sensu lato are the most noteworthy. Given their autoecological profile, these species occur very frequently, albeit with a low cover ratio, in woodland understoreys such as those of Nothofago-Prumnopitydetum, where light availability varies considerably from one place to another. In Table 1 we have highlighted the occurrence of these nanophanerophytes by placing them apart as representatives of communities belonging to the Aritotelienea chilensis subclass. The association which is usually noteworthy as its mantle scrub is the Azaro microphyllae-Aristotelietum chilensis, whose distribution in continental areas not subjected to extreme low temperatures had previously been related to the occurrence of roble-lleuque forests (AMIGO \& al., 2007b).

There are also many examples of species which grow in the dense shade at the foot of the lleuques and therefore grow less vigorously or at a lower phenological rate, and do not develop all their flower or fruit organs. Consequently, they cannot be properly identified as distinct species. 

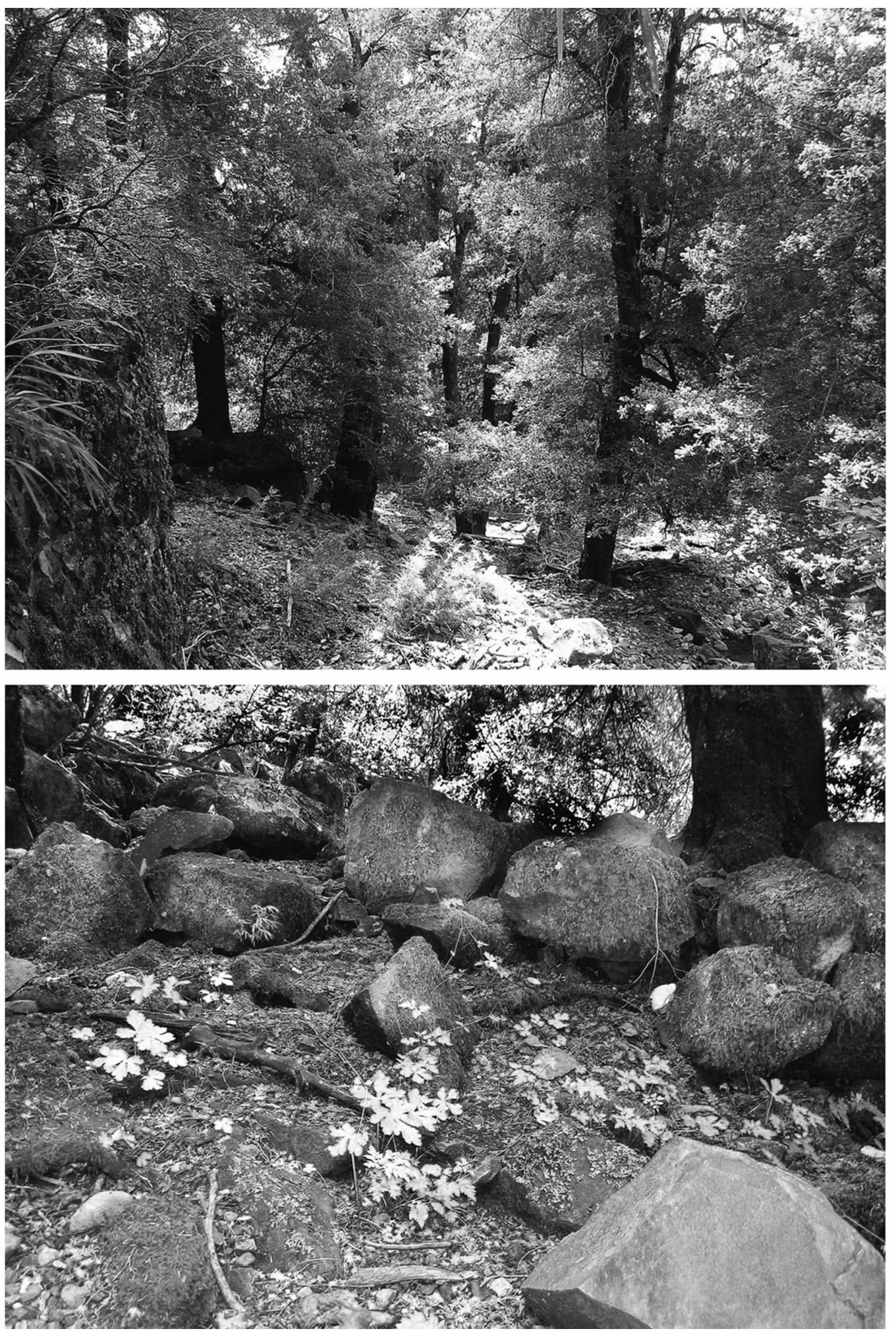

Figure 4.- Internal appearance (top) and detail of the understorey (below) of the lleuque forests under study. 
Table 1 also reveals that the northernmost relevés show the smallest number of species. This is probably because not only is there a smaller surface suitable for making relevés in these sites but also because the coniferous trees "Prumnopitys andina and Austrocedrus chilensis form marginal forests at the dryness limit of the forest region north of $37,5^{\circ}$ south" (HILDEBRAND-VOGEL, 2002: 119). Not surprisingly, in Table 1 relevés 13 and 14, taken on land plots of just $100 \mathrm{~m}^{2}$ in sites north of parallel $37^{\circ}$, have not only the poorest flora of all but also, as a result of their extreme northern location, some of the more spurious species with respect to the usual profile of the association. Relevé no. 13 shows, for example, the occurrence of species such as Aextoxicon punctatum, Laurelia sempervirens, Gevuina avellana or Podocarpus saligna, all belonging to Nothofago-Eucryphion cordifoliae, the most clearly thermophilous flora arrangement within the Wintero-Nothofagetea class. In relevé no. 14 the influence of a markedly sub-Mediterranean temperate bioclimate is not only revealed by the dominance of the ciprés de la cordillera (Austrocedrus chilensis) but also by the presence of species peculiar to the sclerophyllous forests belonging to the Lithraeo-Cryptocaryetea class, such as Quillaja saponaria, Sophora macrocarpa, Chusquea cumingii, Gochnatia foliolosa, or its succesional stages.

\section{ABOUT THE SYNTAXONOMICAL CLASSIFICATION}

With regard to the syntaxonomical classification, we think that the largest number of species relates the Nothofago obliquae-Prumnopitydetum to the Wintero-Nothofagetea class, although for a correct ascription to this class we accept the following assumptions:

1) The interpretation by PollmanN (2001) is correct in extending the Wintero-Nothofagetea class in order to include a series of forests dominated by species which belong to the Nothofagus genus, and present a colder and more continental profile due to the fact that they grow in Argentinian territory. This author defined the Berberido trigonae-No- thofagetalia dombeyi order to comprise several associations suggested by ESKUCHE $(1968,1973)$ as belonging to the Nothofagetea pumilionis-antarcticae class.

2) The supratemperate Argentinian forests dominated by different species belonging to the Nothofagus genus, and even by Austrocedrus chilensis in temperate territories, should be more closely related to their vicariant instances growing in Chile. This can easily be done by subordinating a series of species peculiar to the Nothofagus forests growing on the temperate strip of land in Argentinian territory to the Wintero-Nothofagetea class. However, in the past some researchers of that trans-Andean territory (Eskuche, 1968, 1973 and 1999; ConTiCELLO \& al., 1996) have opted to include these series in the Nothofagetea pumilionis-antarcticae class.

3) Nothofago obliquae-Prumnopitydetum should therefore be included in the Berberido trigonae-Nothofagetalia dombeyi order and, within this order, temporarily in the Austrocedro-Nothofagion dombeyi alliance, which comprises the most clearly sub-Mediterranean communities of the order. Nevertheless, a correct interpretation of the lleuque forests will require still more accurate research on the locations of the Chilean-Argentinian deciduous forests dominated by robles, from Dioscoreo brachyobotryae-Nothofagetum obliquae, described for the territory in Argentina, to Elymo andiniNothofagetum macrocarpae, described for the Chilean sites of the region known as Libertador O'Higgins (parallel $34^{\circ}$ south).

Appendix 2 shows some flora arrangements which we interpret as characteristic or territorial differentials of three phytosociological units whose profile in supratemperate ArgentinianChilean territories is worth clarifying:

+ The first group shows the species which we consider as characteristic of continentalized, supratemperate Valdivian forests included in the Berberido trigonae-Nothofagetalia dombeyi order. Many of these species have previously been interpreted by Argentinian authors as belonging to the Nothofagetea pumilionis-antarcticae 
class, although none of them were included as such by the author suggesting the syntaxa (OBERDORFER, 1960). To these we have also added some others which are more usually found in other syntaxa of the Wintero-Nothofagetea class, but whose presence in the Berberido trigonaeNothofagetalia dombeyi forests can be used as a differential to highlight their non-inclusion in $\mathrm{No}$ thofagetea pumilionis-antarcticae.

+ The second group is made up of scrub and microforest species representing scrub succesional stages of the forests belonging to the above mentioned order. Although we support the name Berberido-Nothofagetalia antarcticae suggested by ESKUCHE (1969) for this unit, we think that some associations originally ascribed to this order are spurious. Ideally this order should be combined with those mantle scrubs and preforests defined for the temperate forests of Chile, that is, included in the Aristotelienea chilensis subclass. As occurs with the preceding case, some of the species chosen for this second group have their optimum in other orders belonging to that subclass. Consequently, their occurrence in the continental area must be interpreted as a differential species.

+ Finally, the third group comprises those species genuinely characteristic of the Nothofagetea pumilionis-antarcticae class, although some others, peculiar to the Nothofagus pumilio forests in the Magallanic Province, could also be added. In this third group, the proportion of species (almost 50\%; those marked as $+\mathrm{W}-\mathrm{N}$ ) more or less frequently found in the supratemperate WinteroNothofagetea forests is particularly worth noting. Consequently, their role as characteristic species must be interpreted as less significant. We think that the distinction Nothofagetea pumilionis-antarcticae versus Wintero-Nothofagetea must be identified with the limit between orotemperate versus supratemperate forests. To properly recognize this limit, the Nothofagus pumilio forests become particularly relevant for diagnostic purposes, given their role as bioindicators for the bioclimatic orotemperate belt, as suggested by AMigo \& al. (2007a).

\section{CONCLUSIONS}

Consequently, we propose the new forest association dominated by the roble (Nothofagus obliqua) and the lleuque (Prumnopitys andina). In the Chilean plant syntaxonomy this association must be included in the Wintero-Nothofagetea class. As a result, we also suggest subordinating to this phytosociological class some syntaxa interpreted in the $20^{\text {th }}$ century by some Argentinian authors as belonging to the Nothofagetea pumilionis-antarcticae class.

\section{ACKNOWLEDGMENTS}

We would like to thank the staff of the Instituto de Botánica of the Austral University of Valdivia for their valuable help and support, Eduardo Castro Rodríguez for his photographic skills and assistance in field research, and the Xunta de Galicia and the University of Santiago for partially financing the time spent in Chile of one of the Spanish authors.

\title{
SYNTAXONOMICAL SCHEME OF THE MENTIONED COMMUNITIES
}

\author{
Wintero-Nothofagetea Oberd. 1960 \\ Wintero-Nothofagenea Oberd. 1960 \\ Laurelietalia philippianae Oberd. 1960 \\ Nothofago-Eucryphion cordifoliae Oberd. 1960 \\ Berberido trigonae-Nothofagetalia dombeyi Pollmann 2001 \\ Myrceugenio-Nothofagion dombeyi (Eskuche 1999) Pollmann 2001 \\ Dioscoreo brachyobotryae-Nothofagetum obliquae Eskuche (1973) 1999 \\ Austrocedro-Nothofagion dombeyi Eskuche 1968 \\ Nothofago obliquae-Prumnopitydetum andinae Amigo, Rodríguez-Guitián \& Ramírez ass. nova
}


Elymo andini-Nothofagion obliquae Oberd. 1960 prov.

Elymo andini-Nothofagetum macrocarpae Oberd. 1960 prov. corr.

Aristotelienea chilensis Amigo, Ramírez \& Quintanilla 2007

Aristotelietalia chilensis (Oberd. 1960) Hildebrand 1983

Berberidion buxifoliae Oberd. 1960

Azaro microphyllae-Aristotelietum chilensis Amigo, Ramírez \& Quintanilla 2007

Berberido-Nothofagetalia antarcticae Eskuche 1969 (excl. Discarietum articulatae)

\section{REFERENCES}

Amigo, J., Izco, J. \& Rodríguez-Guitián, M.A. -2007aRasgos bioclimáticos del territorio templado de Chile - Phytocoenologia 37 (3-4): 739-751.

Amigo, J., Ramírez, C. \& Quintanilla, L.G. -2007b - Mantle communities of the temperate woodlands of South Central Chile: a phytosociological study of the order Aristotelietalia chilensis - Phytocoenologia 37(2): 269-319.

Braun-Blanquet, J. - 1979- Fitosociología. Bases para el estudio de las comunidades vegetales - H. Blume Ediciones. $820 \mathrm{pp}$.

Cabrera, A.L. \& Willink, A. -1973- Biogeografía de América Latina - Secretaría General de la Organización de los Estados Americanos. 117 pp.

CONAF (Corporación Nacional Forestal) -1998- Experiencia silvicultural del bosque nativo de Chile. Recopilación de antecedentes para 57 especies arbóreas y evaluación de prácticas silviculturales - Publicaciones Lo Castillo, Salesianos S.A. Santiago de Chile. $420 \mathrm{pp}$.

Conticello, L., Gandullo, R., Bustamante, A. \& Tartaglia, C. - 1996- Fitosociología de los bosques caducifolios del norte del Departamento Lácar y sur de Huilliches de la provincia de Neuquén (Argentina) - Bosque 17(2): 27-43.

Costa, M. - 2004 - Biogeografía - In: Izco, J. \& cols. (Ed.).

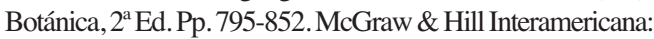

Donoso, C. - 1981 - Tipos forestales de los bosques nativos de Chile - CONAF/PNUD-FAO, Doc. trab. 38. Investigación y Desarrollo Forestal. 70 pp.

Donoso, C. - 1983- Arboles nativos de Chile. Guía de reconocimiento - Univ. Austr. Chile, CONAF X Región. Colección Naturaleza de Chile, vol. 1. 116 pp.

Ellenberg, H. - 1988 - Vegetation ecology of Central Europe. 4th Ed. - Cambridge University Press. Cambridge. 731 pp.

Eskuche, U. - 1968 - Fisionomía y sociología de los bosques de Nothofagus dombeyi en la región de Nahuel Huapi - Vegetatio 16: 192-204.

Eskuche, U. - 1969- Berberitzengebüsche und Nothofagus antarctica-Wälder in NW-Patagonien-Vegetatio 19:264-285.

Eskuche, U. - 1973- Estudios fitosociológicos en el norte de Patagonia. I. Investigación de algunos factores de ambiente en comunidades de bosque y de chaparral Phytocoenologia 1(1): 64-113.
Eskuche, U. - 1999- Estudios fitosociológicos en el norte de la Patagonia. II. Los bosques del Nothofagion dombeyi - Phytocoenologia 29(2): 177-252.

Gajardo, R. - 1994- La vegetación natural de Chile Editorial Universitaria. Santiago de Chile. 165 pp.

Gehu, J.M. \& Rivas-Martínez, S. - 1981 - Notions fondamentaux de phytosociologie - In: Dierschke, H. (Ed.). Syntaxonomie. Pp. 5-53. J.Cramer, Vaduz.

Hechenleitner, P., Gardner, M.F., Thomas, P.I., Echeverria, C., Escobar, B., Brownless, P. \& Martínez, C. -2005Plantas Amenazadas del Centro-Sur de Chile. Distribución, Conservación y Propagación, 1st ed. - Univ. Austr. Chile. Jard. Bot. Edimburgo. 188 pp.

Hildebrand-Vogel, R. - 2002 - Structure and dynamics of southern Chilean natural forests with special reference to the relation of evergreen versus deciduous elements - Folia Geobot. 37: 107-128.

Luebert, F. \& Pliscoff, P. - 2006- Sinopsis bioclimática y vegetacional de Chile - Ed. Univ. 316 pp.

Marticorena, C. \& Quezada, M. -1985- Catálogo de la flora vascular de Chile - Gayana Bot. 42 (1-2): 5-157.

Marticorena, C. \& Rodríguez, R. -1995- Flora de Chile. Vol. I. Pteridophyta-Gymnospermae - Univ. Concepción. Ed. Anibal Pinto. 352 pp.

Marticorena, C. \& Rodríguez, R. -2001 - Flora de Chile. Vol. 2. Winteraceae-Ranunculaceae - Univ. Concepción. Trama Impresores S.A. 99 pp.

Marticorena, C. \& Rodríguez, R. -2003 - Flora de Chile. Vol. 2(2). Berberidaceae-Betulaceae - Univ. Concepción. Impresos Siglo XXI Ltda., Concepción. 93 pp.

Marticorena, C. \& Rodríguez, R. -2005- Flora de Chile. Vol. 2(3). Plumbaginaceae-Malvaceae - Univ. Concepción. Impresos Siglo XXI Ltda., Concepción. $128 \mathrm{pp}$.

Mill, R.R. \& Quinn, C.J. - 2001 - Prumnopitys andina reinstated as the correct name for Lleuque, the Chilean conifer recently renamed P. spicata (Podocarpaceae) Taxon 50: 1143-1154.

Oberdorfer, E. - 1960 - Pflanzensoziologische Studien in Chile - Flora \& Vegetatio Mundi 2: 1-208.

Pollmann, W. -2001-Caracterización florística y posición sintaxonómica de los bosques caducifolios de Nothofagus alpina (Poepp. \& Endl.) Oerst.en el centro-sur de Chile - Phytocoenologia 31(3): 353-400. 
Ramírez, C. \& Figueroa, H. - 1985- Fitosociología de los Nothofagus de la zona higromórfica chilena - Bosque 6: 127-132.

Rivas-Martínez, S. - 1993- Clasificación bioclimática de la Tierra - Folia Bot. Matritensis 11: 1-20

Rivas-Martínez, S. -2007- Mapa de series, geoseries y geopermaseries de vegetación de España (Memoria del Mapa de Vegetación Potencial de España. Parte 1) Itinera Geobot. 17: 5-435

Rivas-Martínez, S. -On-Line-www.globalbioclimatics.es.

Rodríguez, R. - 1988- Lleuque. Prumnopitys andina (Poepp. ex Endl.) de Laub. Ficha Coleccionable Chile Forest. 148: 33-34.

Rodríguez, R., Matthei, O. \& Quezada, M. - 1983 - Flora arbórea de Chile - Univ. Concepción, Concepción. 408 pp.
Rodríguez, R. \& Quezada, M. -1995- Prumnopitys Phil. - In Marticorena, C. \& Rodríguez, R. (Eds.). Flora de Chile, vol I. Pteridophyta-Gymnospermae. Pp. 321-322. Univ. Concepción.

Weber, H.E., Moravec, J. \& Theurillat, J.P. -2000 - International code of phytosociological nomenclature, 3rd ed. - J. Veg. Sci. 11: 739-768.

Woltz, P. - 1985- Place des gymnospermes endémiques des Andes meridionales dans la végétation du Chili Lazaroa 8: 293-314.

Zuloaga, F. \& Morrone, O. (Eds.) -1996- Catálogo de las Plantas Vasculares de la República Argentina. I. Pteridophyta. Gymnospermae y Angiospermae (Monocotyledoneae) - Missouri Bot. Garden. St. Louis. $323 \mathrm{pp}$.

Recibido: 3 septiembre 2009

Aceptado: 25 noviembre 2009

\section{APPENDIX 2}

Characteristic or differential species of the three Valdivian-Magallanic syntaxonomical units of Chile and Argentina.

\begin{tabular}{|c|c|c|}
\hline \multicolumn{3}{|c|}{ Berberido trigonae-Nothofagetalia dombeyi } \\
\hline Anemone multifida Poir. & Cystopteris fragilis (L.) Bernh. & $\begin{array}{l}\text { Myoschilos oblonga Ruiz \& Pavón } \\
\text { (W-N) }\end{array}$ \\
\hline $\begin{array}{l}\text { Austrocedrus chilensis (D.Don) } \\
\text { Pic.Ser. \& Bizzarri }\end{array}$ & $\begin{array}{l}\text { Dioscorea brachyobotrya Poepp. } \\
(\mathbf{W}-\mathbf{N})\end{array}$ & $\begin{array}{l}\text { Polystichum plicatum (Poepp. ex } \\
\text { Kunze) Hicken }\end{array}$ \\
\hline $\begin{array}{l}\text { Berberis trigona Kunze ex } \\
\text { Poepp.\& Endl. (W-N) }\end{array}$ & Elymus andinus Trin. & Relchela panicoides Steud. \\
\hline $\begin{array}{l}\text { Bowlesia tropaeolifolia } \\
\text { Gill. \& Hook. }\end{array}$ & Galium chilensis Endl. & Trisetum caudulatum Trin. \\
\hline Calceolaria filicaulis Clos & Gavilea glandulifera (Poepp.)Correa & Vicia nigricans Hook. \& Arn. \\
\hline Carex patagonica Speg. & Gavilea odoratissima Poepp. & Viola maculata Cav. \\
\hline $\begin{array}{l}\text { Diplolepis descolei (T.Mey.) } \\
\text { Lieder\& Rapini }\end{array}$ & $\begin{array}{l}\text { Maytenus chubutensis (Speg.)Lourt., } \\
\text { O'Don.\& Sleum. }\end{array}$ & \\
\hline \multicolumn{3}{|c|}{ Berberido-Nothofagetalia antarcticae } \\
\hline Azara microphylla Hook.f. (+ Ach) & Geranium patagonicum Hook.f. & $\begin{array}{l}\text { Nothofagus antarctica (G.Forster) } \\
\text { Oerst. (+ Np-a) }\end{array}$ \\
\hline Berberis darwinii Hook. & $\begin{array}{l}\text { Lomatia hirsuta (Lam.) Diels ex } \\
\text { J.F.Macbr. (+ Ach) }\end{array}$ & Ovidia andina (Poepp. \& Endl.) Meisn. \\
\hline $\begin{array}{l}\text { Berberis microphylla G.Forst. } \\
(+\mathbf{A c h})\end{array}$ & Maytenus boaria Mol. (+ Ach) & $\begin{array}{l}\text { Relbunium hypocarpium (L.) } \\
\text { Hemsl.(+ Ach) }\end{array}$ \\
\hline Diostea juncea (Gill. \& Hook.) Miers & Mutisia decurrens Cav. & Ribes cucullatum Hook.et Arn. (+ Np-a) \\
\hline $\begin{array}{l}\text { Festuca purpurascens Banks \& Sol. } \\
\text { ex Hook.f. }\end{array}$ & Mutisia spinosa Ruíz \& Pavón & Ribes valdivianum Phil. (+ Ach) \\
\hline Fragaria chiloensis (L.)Duchesne & $\begin{array}{l}\text { Myrceugenia ovata (Hook. \& Arn.) } \\
\text { Berg var. nannophylla (Burret) } \\
\text { Landrum }\end{array}$ & Schinus patagonicus (Phil.) Johnst. \\
\hline
\end{tabular}


Nothofagetea pumilionis-antarcticae

Adenocaulon chilense Less. (+W-N) Escallonia alpina Poepp. ex DC.

Alstroemeria aurea Graham (+W-N) Gavilea lutea (Pers.) M.N.Correa

Anemone antucensis Poepp.

Arachnitis uniflora Phil. (+W-N) Hypochaeris tenuifolia (Hook.\& Arn.) Griseb. Lagenophora hirsuta Less. (+W-N)

Araucaria araucana K.Koch (+W-N) Leucheria thermarum (Phil.) Phil. Berberis montana Gay $(+\mathbf{W}-\mathbf{N})$ Berberis serrato-dentata Lechler $(+\mathbf{W}-\mathbf{N})$

Cardamine glacialis (G.Forster) DC. Nothofagus pumilio (Poepp. \& Endl.) Krasser (+W-N)

Codonorchis lessonii (Brongn.) Lindl. Perezia pedicularifolia Less.

Drimys andina (Reiche) R.A. Rodríguez \& Quezada (+W-N)

Embothrium coccineum J.R. Forster \& G.Forster (+W-N)
Ribes magellanicum Poir. (+W-N)

Ribes nitidissimum Neger

Rubus geoides J.E.Sm. (+W-N)

Senecio acanthifolius Hombr. \& Jacq.

Senecio pilquensis H.Buek

Senecio prenanthifolius Phil.

Uncinia negeri Kuckenthal

Valeriana lapathifolia Vahl (+W-N)

Viola reichei Skottsb. ex Macloskie $(+\mathrm{W}-\mathrm{N})$

Top: continental, supratemperate, Valdivian-Magallanic forests (Chile and Argentina): Berberido trigonae-Nothofagetalia dombeyi. The species which tend ideally to occur in other woodland communities belonging to different orders of the Wintero-Nothofagetea class are marked with $(\mathbf{W}-\mathbf{N})$.

Middle: continental scrub and microforests: Berberido-Nothofagetalia antarcticae. The species peculiar to other Aristotelietalia chilensis communities and acting as differentials are marked with (Ach). Some cases marked with (+ Np-a) are considered by other authors as characteristic of the Nothofagetea pumilionis-antarcticae class.

Below: orotemperate, Valdivian-Magallanic forests: Nothofagetea pumilionis-antarcticae. The species which are usually found in supratemperate Wintero-Nothofagetea forests are marked with $(+\mathbf{W}-\mathbf{N})$. 